\title{
A Policy Shift from State to Non-state in Education Aid: A Critical Discourse Analysis of the UK's Development Policies
}

\author{
Thu Ya Aung \\ Texas State University \\ Rolf Straubhaar \\ Texas State University
}

\begin{abstract}
Due to the historically outsized influence of the United Kingdom's development assistance office on international aid, a better understanding of the underlying ideologies and political priorities guiding this agency would help the larger aid community more clearly understand the power dynamics and structural context of the development industry. However, these ideologies and dynamics are often left implicit and are not always easily understood. The purpose of this article is to use critical discourse analysis to unpack the ideologies, political priorities and power dynamics present in DfID's official education policy documents. In so doing, we make the implicit explicit, and begin to unpack the implicit meanings and assumptions that are present in these written texts, particularly regarding the deprioritized role of the state in providing a high-quality education. We argue that this analysis reveals an underlying perception within DfID that the private sector is more effective at providing public education in developing countries than the public sector.
\end{abstract}

The Department for International Development (DfID) ${ }^{i}$ was a department under the United Kingdom (UK) Government responsible for administering UK official development assistance (ODA). The UK stood in third place after the United States and Germany among the Organisation for Economic Co-operation and Development (OECD) Development Assistance Committee list of donor countries, contributing $12.7 \%$ of total global ODA in 2019ii (FCDO, 2020). The UK contributes its ODA as both bilateral aid (i.e. aid earmarked for particular aid-receiving countries) and multilateral aid (i.e. as a part of an unearmarked pooled global fund). In 2019, the UK's bilateral development aid accounted for $67.5 \%$ of its total ODA, and it saw an overall upward trend from $63.2 \%$ in 2015 (FCDO, 2020). Bilateral ODA allows the donor country (in this case, the UK) to choose the priority areas they will support in aid-receiving countries, reflecting more directly the priorities of their citizens and taxpayers, while multilateral ODA is generally considered politically neutral (Kilmister, 2016). In 2019, Africa received the largest share $(50.6 \%)$ of the UK's bilateral ODA, followed by Asia (41.8\%), Americas (4.1\%), Europe $(3.2 \%)$, and the Pacific (0.3\%). Pakistan, Ethiopia, and Afghanistan were the top 3 countries receiving the UK's country-specific bilateral ODA (FCDO, 2020).

Since DfID is among the largest donors listed by the OECD's Development Assistance Committee, its underlying ideologies and political priorities have the potential to exert 
enormous influence on education policy in aid-receiving developing countries. However, while understanding these underlying ideologies and priorities would help aid-receiving countries, scholars and lay observers to better understand the larger aid policy environment, they are typically not stated explicitly so as to be easily understood. In response, the purpose of this article is to unpack these ideologies and priorities using DfID official policy documents, with the goal of making the implicit explicit. To do this, we use critical discourse analysis (Fairclough, 1995) to analyze DfID's four primary education policy documents issued between 2010 and 2018, with the purpose of examining and unpacking the implicit meanings and assumptions that are present in these written texts.

To reach this aim, we will first ground this work in the established literature, reviewing the growing role the private sector has played in educational provision in developing countries, as well as the use of critical discourse analysis to examine the relationships between developing countries' education policies and international aid organizations. We will then describe our methodology based in critical discourse analysis, before delving into our findings. As we will argue here, DfID's educational policy documents contain powerful rhetoric on the role of the state in providing education, implying a strong ideological stance regarding the relative efficacy of state versus non-state actors in providing a high-quality education. More specifically, we argue that the rhetoric used in these DfID documents demonstrates the perception that public education in developing countries has failed, while the private sector provides a degree of quality and outreach the public sector lacks.

\section{Private Sector in Education of Developing Countries}

Private schools for the wealthy have not been unusual in developing countries. However, starting in the 1990s, a large number of low-cost private schools have emerged in the poorest parts of the developing world, particularly in slums and rural areas (Heyneman \& Stern, 2014; Lewin, 2007; Tooley, 2004; Tooley et al., 2011). There is a wide spectrum of relative government support and regulation regarding those low-cost private schools, from non-existent to official government sponsorship through voucher programs, which buy seats in private schools for needy students, or contract out private firms to run public schools (Heyneman \& Stern, 2014).

In their research in six African and South Asian countries, Tooley et al. (2011) categorized low-cost private schools into three categories: government-aided, governmentrecognized, and government-unrecognized. The government-recognized status allows a school to organize state examinations and to issue official graduation paperwork, meaning students who attend these schools can continue to a higher level of schooling and have better employment opportunities (Tooley et al., 2011). Parents' motivation to send their children to low-cost private schools often relates to the perceived better quality of those private schools or the inability of public education systems to reach the poorest areas, especially the fastest growing city slums (Heyneman \& Stern, 2014; Tooley et. al, 2011). The proliferation of low-cost private schools in developing countries related to the pressure of the Education for All policy agenda on those countries whose public education systems could not respond to a dramatic increase of enrollment in basic education within the Educational for All timeframe (Lewin, 2007; Rose, 2005). 


\section{The Impact of Low-Cost Private Schools}

There has been a debate around whether or not low-cost private schools have a positive impact on the education systems of developing countries (Heyneman \& Stern, 2014; Lewin, 2007; Tooley, 2004; Tooley et. al, 2011). Professor James Tooley from the United Kingdom is an ardent advocate of low-cost private schools, and he advocates for governments to relinquish their role as education providers (Wilby, 2013). Tooley (2004) boldly asserted that "government schools cannot provide quality education for all," referring to the Probe Team's 1999 Public Report on Education in India and the 2000 Oxfam Education Report by Watkins as examples of how low-cost private schools are better than their public counterparts (p. 4). Tooley (2004) has claimed that public schools in many developing countries lack accountability, have chronic teacher absenteeism, and little time on task for students. Watkins (2004), who wrote the Oxfam Education Report that Tooley draws upon, argued in response that Tooley "selectively interprets and then misinterprets" the findings from the Oxfam report and the Probe Team report to advocate for low-cost private schools (p. 8). Watkins has argued that state education systems in developing countries can deliver quality education if there are "participative and accountable structures" in politics, whereas "wholesale privatization" of the basic education delivery will deepen inequality (Watkins, 2004, p.11).

On a similar note, Lewin (2007) has concluded that low-cost private schools have only "a limited impact" in achieving universal access to education in South-Saharan Africa (p.18). While recognizing that private schools have expanded access to education, Lewin pointed out that they do not reach children from the poorest $20 \%$ at the primary level and more children at the secondary level (Lewin, 2007). Based on their multi-country case studies of low-cost non-government schools in Jamaica, Kenya, Tanzania, Ghana, Indonesia, and Pakistan, Heyneman and Stern (2014) have recommended that non-government schools must be regulated and included in governmental education management systems. As can be seen in this review of the literature there is still debate on whether the expansion of low-cost private schools in developing countries ameliorates educational inequality or exacerbates it.

Another crucial question is whether low-cost private schools do better than public schools in promoting student academic achievement. Several studies have demonstrated evidence that low-cost private schools do promote higher student achievement, at least as measured by standardized tests. Tooley et al. (2011) randomly selected low-cost private schools and public schools in Lagos, Nigeria, and in Delhi and Hyderabad, India to compare the performance of students from unrecognized private schools, staterecognized schools, and zero-tuition, state-run schools. Their results show that students from both government-recognized and government-unrecognized private schools outperformed their counterparts from state-run schools (Tooley et al., 2011). In a similar study of low-cost private schools in Brazil, students from two Brazilian high schools with a co-management model based in public-private partnerships outperformed their publicschool counterparts in state examinations (Chattopadhay \& Nogueira, 2014).

However, while these two studies (Chattopadhay \& Nogueira, 2014; Tooley et al., 2011) found private schools to outperform their public counterparts in student achievement, 
Heyneman and Stern's (2014) found only mixed results in comparing low-cost private schools and public schools in Jamaica, Kenya, Tanzania, Ghana, Indonesia, and Pakistan. Another rigorous review of 59 studies by Ashley et al. (2014) showed that private school students outperformed compared with their public-school counterparts, but "there is ambiguity about the size of the true private school effect," and "many children may not be achieving basic competencies even in private schools" (p. 1). Since findings pointed to some critical gaps in evidence, Ashley et al. (2014) concluded: "What is clear... is the need for more targeted research to fill the gaps in our understanding of the role and impact of private schools in developing countries" (p. 3). While this study does not provide the type of quantitative evidence for or against low-cost private schools outlined in this literature review, it does document how, despite the lack of consensus in the academic literature regarding the impact of low-cost private schools, staffers and report writers at institutions like DfID already hold opinions and beliefs regarding the relative strength of public and private schools in developing countries, and those opinions are revealed through their rhetoric and word choice. Before examining that rhetoric and word choice with our own critical discourse analysis, we will now explore the literature on previous studies that have engaged in similar forms of critical discourse analysis on governmental policy documents.

\section{Policy Relationships Between Developing Countries and International Organizations: Insights from Critical Discourse Analysis}

International organizations have exerted influence on the education policy development process across the developing world. Most aid-receiving countries receive technical or financial assistance from "development partners" or donors, like DfID (Baxter, 2010; Birbirso, 2013; King, 2007; McCormick, 2011, 2012, 2014, 2016; Nuzdor, 2013; Rappleye, 2011; Shajahan, 2012).

In the existing literature, scholars have conducted critical discourse analysis of education policies and public policy documents from developing countries like the Lao People's Democratic Republic, Cambodia, and Ghana, revealing that influence from international organizations has led to the emergence of hybrid discourses of 'global' education ideologies in developing world contexts (see McCormick, 2012; Nuzdor, 2013). Nuzdor (2013) analyzed selected documents on Ghana's Free Compulsory Universal Basic Education (fCUBE) policy and revealed that in these documents there was a discursive shift from rights-based social democratic ideals to a neoliberal discourse focused on economic concerns. Specifically, Nuzdor (2013) found a link between this neoliberal discursive shift and when Ghana began to implement World Bank-supported policy strategies.

In the Lao People's Democratic Republic (Lao PDR) and Cambodia, McCormick (2012) found similar neoliberal, individual-centric globalization discourses from international organizations, though in those cases that outside rhetoric mixed more strongly with existing centralized bureaucratic discourses within the existing policy structures of these two countries. McCormick (2012) noticed that in both Lao PDR and Cambodia, there were intertextual links between both countries' national constitutions and Education for All (EFA) documents that, when analyzed, revealed a power struggle for dominance in the policy discourse between local governments and international organizations. For 
instance, the Laotian constitution carried traces of both socialist ideas of nation-building alongside neoliberal tenets of privatization with regard to education. McCormick's analysis of education policy documents in Lao PDR and Cambodia led him to conclude that "access to formal, primary education is promoted in the service of growth, and private provision to the benefit of the few, at the expense of improving quality in education for the marginalized or even the poor majority" (McCormick, p. 39). While these documents contained competing discourses of socialism and neoliberalism, in the end the neoliberal trend won out and held the greater way over policy (for similar results in Papua New Guinea and Vanuatu, see McCormick, 2011, 2014, 2016).

At times, the literature has shown instances when imported "modern" ideas result in unintended negative consequences when implemented. Through a critical discourse analysis of the Ethiopian education reform policy for broadcasting secondary school lessons from the capital city Addis Ababa to outlying rural areas, Birbirso (2013) found the policy had come about due to external pressures from funding agencies, resulting in what he referred to as a form of technological determinism, in which local teachers only need to serve as the "gatekeepers of the screen teacher" (p. 196). According to Birbirso's (2013) argument, this remote education policy represented the type of failure that comes from (over)technologizing education, replacing local classroom teachers' expertise with pre-recorded broadcasted lessons that need only be "facilitated" on the ground locally.

Another portion of the literature that utilizes critical discourse analysis to examine the relationship between international aid organizations and policy in developing countries is focused on higher education policy, and comes to similar conclusions to the studies cited above. In terms of more theoretical contributions, Shajahan (2012) studied the role of four international organizations (UNESCO, the World Bank, the OECD, and the European Union) in globalizing higher education policy, arguing that these international organizations serve as "discursive forces" (p. 380) which shape the way policymakers think about learning, education policy, and education in general. Shajahan (2012) contended that these organizations have such force due to developing countries' dependence on their technical and / or financial support.

A number of scholars made similar arguments with country-specific studies. For example, Baxter's (2010) comparative textual analysis of the World Bank's 2002 higher education policy and the 2008 higher education policy of the Rwandan Ministry of Education reveal that discourses based in human capital theory and a general market-oriented view towards the education sector which are prevalent in the World Bank documents are also interestingly replicated and reflected in Rwanda's educational policies. Baxter also found that such discourses were present in the vision and mission statement of public institutions of higher education in Rwanda. Similarly, Julia Preece (2013) analyzed policies related to lifelong learning in Lesotho and Tanzania, arguing that international aid organizations' neoliberal influence on both countries had been negative, marginalizing the discourses of indigenous African worldviews. Koch and Weingart (2016) argued that the silencing of alternative discourses perpetuated long-standing inequalities, with government policy agendas being "hijacked" (p. 179) by foreign experts from international organizations when aid dependency in developing countries is high. Koch 
and Weingart (2016) concluded that "the prevailing sentiment of being at the mercy of donors has paralysed leadership and administration which fails to set or refrains from articulating an agenda of its own" (p. 208).

Critique of international organizations' development policies has also come from feminist perspectives (see Roberts, 2015). Notably, Monkman and Hoffman (2013) used feminist critical discourse analysis to analyze three hundred policy documents published by 14 organizations between 1995 and 2008. They found that across these documents, education policy was effectively narrowed in three different ways: first, the logic of the arguments is left unexplained; second, policies are not grounded by theories; and third, superficial accountability notions are used (such as comparative headcounts of male and female students). Notably, many documents they analyzed revealed the policy agenda of girls' education focused on improving their "performance in traditional female roles" (p. 79), a move that paradoxically perpetuates the very gender disparities that international organizations claim to challenge.

Overall, the existing literature has shown that policy documents created by international funding organizations, such as (in our case) DfID, are a rich data source to be mined using critical discourse analysis, as the language used in such documents reveals a great deal about the motivating ideologies and political priorities of the people in these organizations. Furthermore, this review of the literature has shown why this type of analysis is urgently needed, as these prior studies have revealed the extent to which these policy documents have influenced national policies in aid-receiving countries. In the following sections, we will build upon this literature with our study of the implicit ideologies and political priorities revealed in DfID's policy literature.

\section{Methods}

Our primary means of data analysis in this study is critical discourse analysis (Fairclough, 1995, 2001). The primary use of critical discourse analysis is to unpack the implicit meanings and assumptions inherent in texts, and by so doing reveal the larger ideologies and social structures that inform those texts (Fairclough, 1995, 2001). More specifically, we operationalize critical discourse analysis as the act of taking a piece of writing or a speech act (in other words, a form of discourse) and trying to understand not only the explicit, surface-level meaning of what is being written or said, but also trying to identify and understand any underlying messages that are being communicated to the listening or reading audience.

In this article, the pieces of writing in question are the four primary policy position documents created within DfID from the period between 2010 and 2018. We have included these documents because they represent the clearest distillation of DfID's position on the current global state of education, as each of the four documents were prepared as position documents which represented the UK governmental position on international education policy at the time of preparation (namely, in 2010, 2013, 2015, and 2018). The first document chronologically (2010) was produced through the UK National Audit Office by DfID officers, and the following three (2013, 2015 and 2018) were produced internally within DfID. 
In this article, we are particularly interested in the implicit meanings communicated within DfID's educational policy documents regarding the role of the state in providing education, and the efficacy of state versus non-state actors in providing an education of high quality. In the following section, we explore our findings from that analysis in greater depth.

\section{Findings}

In our analysis of the DfID policy documents identified above, we found that all four documents followed a common narrative: namely, they began by creating a sense of urgency around the need for global educational reform, followed by arguments that such reform was urgently needed due to the incompetence of current public educational systems, ending with a focus on how educational policy should focus more on the intended recipients of reformed systems (namely, the poor and the marginalized) rather than the means of delivery of those systems (i.e. private versus public). Each of these narrative steps will be explored in turn. As the reader will see, this rhetoric becomes more and more explicit as these documents progress chronologically, with the 2018 document containing the most explicit examples. As a result, the reader will also see more examples cited from the 2018 document than from its predecessors.

\section{Creating a Sense of Urgency}

DfID's education policy documents assert that there is a learning crisis in developing countries. This assertion is supported by using shocking figures: for example, "Over 90 percent of primary-age children in low-income countries and 75 percent of children in lower-middle income countries-more than 330 million children-are not expected to read or do basic maths by the end of primary school" (DfID, 2018, p. 3). In the 2018 DfID policy statement, it is argued then that developing countries' curricular priority should be basic literacy and numeracy. For example:

Education systems in many developing and conflict-affected countries do not incentivise progress on basic literacy and numeracy....DFID's response will focus on tackling the learning crisis at its root by supporting children to learn the basics of literacy and numeracy (DfID, 2018, p. 3).

DFID's mandate to end extreme poverty means that our main objective will be ensuring children learn the basics of literacy and numeracy...tackling the learning crisis at its root. (DfID, 2018, p. 9)

Although it is true that basic literacy and numeracy are important foundational skills for education, and the statistics that precede these policy statements do display there is a lot of work to reach these goals, it is notable that urgency is given to these positions when they have effectively been the subject of global, multilateral efforts for decades, first through the Millennium Development Goals (James, 2006) and later the Sustainable Development Goals (Nazar et al., 2018). This reflects a long-standing trend in developed country policy in both domestic and international affairs (see, for example, the way the Reagan administration utilized the report A Nation At Risk), in which rhetoric implying urgency is used to promote the government's policy agenda (McIntush, 2000). 


\section{Framing Public Education Systems as Incompetent}

Across all four DfID policy documents we analyzed, public education systems in developing countries are portrayed across the board as being incompetent. More specifically, they are often described as not providing marginalized children and girls with access to education. These comments are common enough across all four documents that we organized them in Table 1 below. As can be seen, this rhetoric grows in degree chronologically across the four reports, with the 2018 report containing the largest and most explicit number of examples.

Table 1. Framings of Public Systems as Incompetent.

\begin{tabular}{|c|c|}
\hline Source Document & Pertinent Quotes \\
\hline $\begin{array}{l}\text { Bilateral Support to Public } \\
\text { Education (2010) }\end{array}$ & $\begin{array}{l}\text { Data on costs and progress in countries is generally weak and } \\
\text { incomplete (p. 5). } \\
\text { [Enrollment] is not a sufficient measure of access to education } \\
\text { because pupil dropout in developing countries is high, and the } \\
\text { amount of education delivered and received is low (p. 6). } \\
\text { Pupil attainment has been poorly measured.... High } \\
\text { enrollment increases the proportion of children from } \\
\text { uneducated families, increasing the difficulty of improved } \\
\text { attainment (p. 6). } \\
\text { On teacher performance, we found growing awareness of } \\
\text { problems but as yet little success in securing improvement (p. } \\
\text { 7). } \\
\text { School inspection arrangements exist in each country we } \\
\text { visited, but are not fully functional or resourced (p. } 7 \text { ). } \\
\text {... available evidence indicates that aided education systems } \\
\text { remain inefficient, consuming scarce existing financial and } \\
\text { human resources (p. 9). } \\
\text { Student completion and attainment, however, remain low (p. } \\
\text { 18). } \\
\text { Gender parity remains a major challenge in countries where } \\
\text { culture and religion influence girls' enrollment and retention } \\
\text { (p. 18). } \\
\text { Countries find it difficult to enrol the last } 5 \text { to } 10 \text { per cent of } \\
\text { children, comprising } 2.6 \text { the most excluded and poorest, often } \\
\text { found in rural areas (p. 19). } \\
\text { Course completion is off-track to achieve the Millennium Goal, } \\
\text { reflecting high numbers of children who enrol but } \\
\text { subsequently drop out of school (p. } 19 \text { ). } \\
\text {...available data show low standards and little or no progress } \\
\text { (p. } 21 \text { ). } \\
\text { DFID education teams acknowledge that low attainment may } \\
\text { also indicate poor quality education and teaching in large } \\
\text { classes (p. 23). }\end{array}$ \\
\hline
\end{tabular}




\begin{tabular}{|c|c|}
\hline & $\begin{array}{l}\text { Teachers are not delivering the volumes of teaching required } \\
\text { (p. 27). }\end{array}$ \\
\hline $\begin{array}{l}\text { Improving Learning, } \\
\text { Expanding Opportunities } \\
\text { (2013) }\end{array}$ & $\begin{array}{l}\text {...clearly more needs to be done, and done differently, to } \\
\text { ensure all girls and boys can access a quality education and } \\
\text { learn (p. 3). } \\
\text { Rural girls from the poorest families are locked out of } \\
\text { education in } 10 \text { countries, and at least half of poor, rural girls } \\
\text { have never been to school (p. 6). } \\
\text { DfID's bilateral programme is well aligned to fragile states and } \\
\text { countries furthest from meeting the education MDGs (p. 7). } \\
\text { In some fragile and conflict-affected states, where it may be } \\
\text { more difficult to work through government... (p. 11). } \\
\text { DfID works with the private sector in situations where the } \\
\text { public sector is not sufficiently present (the slums of Nairobi } \\
\text { for example) or where state provision is so weak that the } \\
\text { private sector has stepped in to fill the gap (p. 13). }\end{array}$ \\
\hline $\begin{array}{l}\text { Government Policy: } \\
\text { Education in Developing } \\
\text { Countries (2015) }\end{array}$ & $\begin{array}{l}\text { More than } 57 \text { million children around the world do not go to } \\
\text { primary school. At least } 250 \text { million children cannot read or } \\
\text { count, even if they have spent four years in school (p. 3). } \\
\text { Every child should have the chance to go to school. But it's not } \\
\text { just about getting them into the classroom. It's also about } \\
\text { making sure they are well taught and that what they learn } \\
\text { actually improves their opportunities in life (p. 3). } \\
\text { [By 2015, we will] spend half of our direct education aid on } \\
\text { unstable or war-torn countries where more than two-fifths of } \\
\text { the world's out-of-school children are found, and where a lack } \\
\text { of education can directly contribute to conflict (p. 3). } \\
\text {..large proportions of children in sub-Saharan Africa and } \\
\text { South Asia [are] still not making it into the classroom (p. 3). } \\
\text {... evidence shows girls are disproportionately excluded from } \\
\text { education and that educating girls helps lift whole } \\
\text { communities out of poverty (p. 4). } \\
\text { The Girls' Education Challenge (GEC) will help up to a million } \\
\text { of the world's poorest girls have an opportunity to improve } \\
\text { their lives through education (p. 4). }\end{array}$ \\
\hline $\begin{array}{l}\text { Get Children Learning } \\
\text { (2018) }\end{array}$ & $\begin{array}{l}\text { Business as usual will not achieve the transformative change } \\
\text { that is needed (p. 1). } \\
\text { Yet many teachers lack the knowledge and skills to do their } \\
\text { jobs well. Too often, they are absent from the classroom, } \\
\text { meaning that precious resources go to waste and the potential } \\
\text { of their students is unfulfilled (p. 1). } \\
\text { We will support national leaders ready to take a fresh look at } \\
\text { how their workforces are recruited, trained and motivated, so } \\
\text { that they can make the bold changes that are needed (p. 1). }\end{array}$ \\
\hline
\end{tabular}




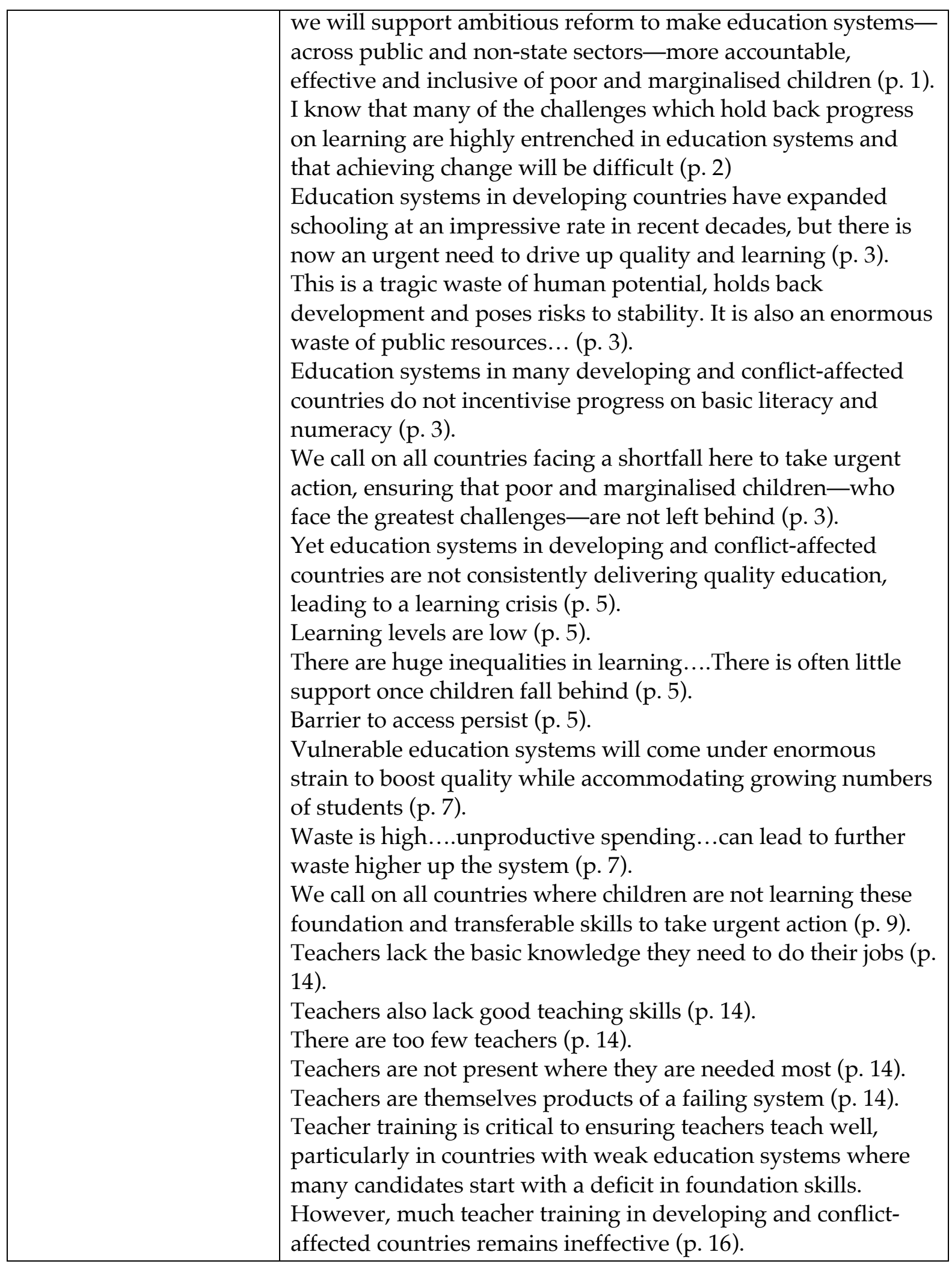




\begin{tabular}{|l|l|}
\hline Many education systems remain focused on getting more \\
children into school, rather than improving quality and \\
learning (p. 19). \\
System incentives to ensure poor and marginalized children \\
are learning the basics are weak (p. 19). \\
Many education systems lack coherence (p. 19). \\
We will help national decision-makers to establish a clear \\
picture of how their education system is working through good \\
diagnosis...We will also support more effective spending, \\
through cutting waste (p. 20). \\
In most developing countries, overall levels of learning are low, \\
but poor and marginalised children usually learn the least (p. \\
23). \\
In most developing and conflict-affected countries, there is an \\
enormous gap between policy and delivery on supporting \\
children with disabilities and little evidence on successful \\
interventions which can be delivered affordably at scale (p. 26).
\end{tabular}

The reader may note that in these quotes, nearly all areas of the public education sector are seen as lacking-student enrollment, student attainment, student content mastery, teaching students with disabilities, gender parity, education in fragile contexts, teacher training, and teacher retention. Some quotes, particularly from the 2018 document, implicate entire public school systems, stating that they "lack coherence" (DfID, 2018, p. 19), are "not consistently delivering quality education" (DfID, 2018, p. 5) and are not sufficiently "accountable, effective and inclusive" (DfID, 2018, p. 1) for their "unproductive spending" (DfID, 2018, p. 7).

Across the board, unlike previous DfID documents, DfID (2018) used particularly strong language to describe developing country education systems:

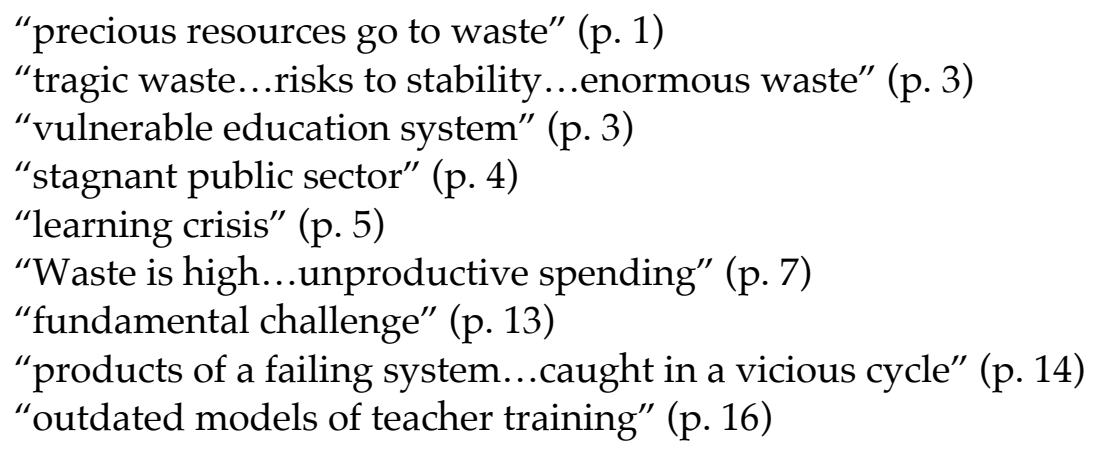

This change to the use of very negative language seems to reflect a shift in DfID's organizational orientation towards public education systems in developing countries, moving from labeling them as from being "weak" (DfID, 2010, p. 5) to being emblems of government "waste" (DfID, 2018, p. 1, 3, 7). In the following section, we will explore rhetoric that may help to explain this shift, as we argue that DfID's policy language (as 
well as their material forms of policy support) overall has shifted over time to prioritize non-state over state actors.

\section{Justifying the Policy Shift}

Particularly in their 2018 document, DfID's language choices in how they describe the work of state and non-state educational institutions make their policy preferences very clear. For example, compare how state public educational institutions are described in the following quote:

System incentives to ensure poor and marginalised children are learning the basics are weak.... To deliver on quality and learning, these incentives will need to change (DfID, 2018, p. 19).

This language corresponds with the descriptions we have explored above. In this section, we want to extend that argument by comparing this consistent negative description of state public educational institutions with the following descriptions of non-state or private schools and public-private partnerships (DfID, 2018):

... public-private partnerships which improve access to education for poor and marginalised children (p. 21).

Through a voucher scheme, new schools programme and subsidies to existing low fee private schools, over 2.5 million students are accessing free of charge primary and secondary schools (p. 21).

Non-state providers, including low-cost private schools, play an important-and growing-role in delivering education in low- and middle-income countries.... Many pupils attending private schools come from low-income families (p. 22).

It is essential that where DfID supports non-state providers and public private partnerships, they work for poor and marginalised children (p. 22).

...private sector partnerships to support more children with disabilities in special and mainstream schools (p. 26).

Compare these positive descriptions of private initiatives to the previous descriptions of public state ones-private education is described as improving access for the poor and vulnerable, while state initiatives are labeled as forms of waste and failure. Such descriptions have clear implications: not only is private education implied to be more effective, but the more socially just option over public education. A contrast is subtly made between the public education systems as being pro-rich (as the rich benefit from "government waste") and private education (which is ironically structured for-profit) as being pro-poor. It is implied that public education systems do not reach marginalized and poor children, and low-cost private schools fill this gap. The way these documents frame this contrast is used to justify DfID's policy shift from primarily supporting public education systems to diverting supports to private entities and public-private partnerships, a trend which corresponds to the same time period represented by these documents (2010-2018). 


\section{Discussion and Conclusion}

In its funding, DfID is increasingly diverting more development aid from public education systems in developing countries to non-state entities. As we have shown in our findings here, we argue that to justify this aid policy shift, DfID documents use negative language which portrays public education systems in developing countries in its policy documents as inefficient, failing manifestations of government waste. In so doing, the authors of these reports create a sense of urgency for reform, and then portray non-state education actors (including low-cost private schools) as the solution to this crisis. Private initiatives and public-private partnerships are described as serving the disadvantaged groups left unattended by current public systems.

Through this kind of writing, the authors of these reports provide ideological justification for DfID's increasing support of non-state education aid. As we have noted previously, this kind of rhetoric becomes more explicit and common in these reports as the reports progress chronologically, with the 2018 report containing the largest number of examples. Over this same time frame, DfID's investment in non-state education providers has increased. We do not see this correlation as occurring by coincidence.

Interestingly, DfID has funded reviews of research on private education (Ashley et al., 2014) whose findings do not support their unambiguously pro-private policy stance. Specifically, Ashley et al. (2014) found that the evidence on the relative effectiveness of private DfID-funded educational initiatives is inconclusive and varied, as we explored at length earlier in the literature review.

DfID has already faced criticism for its pro-private education policy stance in developing countries. An alternative report presented to the UN's Committee of Economic, Social and Cultural Rights (CESCR) submitted by 18 non-government organizations argued that policies prioritizing private education have a negative impact on the right to education in developing countries and may create social stratification in those countries, as not all children have access to non-state institutions (Right to Education, 2015). Referring to the Convention on the Rights of the Child, the report asserts that the UK "could be violating its extra-territorial obligations" in the policy stances taken by DfID (Right to Education, 2015 , p. 3). Through the arguments we make in this article, we agree with the Right to Education (2015) coalition that the unquestioned pro-private policy stance represented by DfID's policy documents merits further questioning, particularly in the face of compelling evidence to the contrary (Ahsley et al., 2014).

\section{Acknowledgments}

The authors have no known conflict of interest to disclose.

The authors would like to thank Dr. Jim Koschoreck and the School Improvement doctoral program at Texas State University for their support of the research that formed the basis of this work.

Correspondence concerning this article should be addressed to Rolf Straubhaar, Texas State University, 601 University Drive, San Marcos, TX 78666.

Email: straubhaar@txstate.edu 
Thu Ya Aung is a doctoral student in School Improvement at Texas State University. Prior to his doctoral studies, he was an education officer with UNICEF and English teacher in his home country of Myanmar.

Rolf Straubhaar is an Assistant Professor of Educational Leadership and School Improvement at Texas State University. Prior to transitioning to academia, he was an elementary school teacher and adult educator in the US, Brazil and Mozambique.

\section{References}

Ashley, D.L. et. Al. (2014). The role and impact of private schools in developing countries: A rigorous review of the evidence (Final report, Education Rigorous Literature Review). DFID.

Baxter, A. (2012). Higher education mission and vision in Rwanda: A comparative and critical discourse analysis. Reconsidering Development, 2,1-26.

Birbirso, D. T. (2013). Technology for empowering or subjugating teachers: Analysis of Ethiopia's education reform discourse practice. Journal of Critical Education Policy Studies, 11, 179-201.

Chattopadhay, T., \& Nogueira, O. (2014). Public-private partnership in education: A promising model from Brazil. Journal of International Development, 26, 875-886.

DfID (2013). Education position paper: Improving learning, expanding opportunities. DfID.

DfID (2015). 2010 to 2015 government policy: Education in developing countries. DfID.

DfID (2017). Statistics on international development 2017. London, UK: DfID.

DfID (2018). DFID education policy: Get children learning. London, UK: DfID.

Donor Tracker. (n.d.). United Kingdom. https://donortracker.org/country/unitedkingdom

Fairclough, N. (1995). Critical discourse analysis: The critical study of language. Pearson.

Fairclough, N. (2001). Critical Discourse Analysis as a method in social scientific research. In R. Wodak and M. Meyer (Eds.), Methods for critical discourse analysis (p. 121-138). Sage.

FCDO. (2020). Statistics on international development: Final UK aid spend 2019. UK: FCDO. Full Fact. (2018, February 15). UK spending on foreign aid. https: / / fullfact.org/ economy/uk- spending-foreign-aid/

Global Partnership for Education. (2019). United Kingdom. https: / / www.globalpartnership.org/about-us/donor/ united-kingdom 
Heyneman, S. P., \& Stern, J. M. B. (2014). Low-cost private schools for the poor: What public policy is appropriate? International Journal of Educational Development, 35, 315.

King, K. (2007). Balancing basic and post-basic education in Kenya: National versus international policy agendas. International Journal of Educational Development, 27, 358-370.

Koch, S., \& Weingart, P. (2016). The delusion of knowledge transfer: The impact of foreign aid experts on policy-making in South Africa and Tanzania. London, UK: African Minds.

Lewin, K. M. (2007). The limits to the growth of non-government private schooling in Sub Saharan Africa. CREATE, Center for International Education, University of Sussex.

McCormick, A. (2011). Some partners are more equal than others: EFA and civil society in Papua New Guinea and Vanuatu education policy processes. International Education Journal: Comparative Perspectives, 10, 54-70.

McCormick, A. (2012). Whose education policies in aid-receiving countries: A critical discourse analysis of quality and normative transfer through Cambodia and Laos. Comparative Education Review, 56, 18-47.

McCormick, A. (2014). Who are the custodians of Pacific 'post-2015' education futures? Policy discourses, education for all and the millennium development goals. International Journal of Education Development, 39, 173-182.

McCormick, A. (2016). Vanuatu education policy post-2015: 'Alternative' decolonising processes for 'development'. The international Journal: Comparative Perspectives, $15,16-29$.

McIntush, H. G. (2000). Defining education: The rhetorical enactment of ideology in A Nation at Risk. Rhetoric E Public Affairs, 3(3), 419-443.

Monkman, K., \& Hoffman, L. (2013). Girls' education: The power of policy discourse. Theory and Research in Education, 11, 63-84.

National Audit Office. (2010). Bilateral Support to Primary Education. National Audit Office.

Nudzor, H. P. (2013). Unearthing the discursive shift in the 'fCUBE' policy implementation in Ghana: Using critical discourse analysis. International Journal of Research \& Method in Education, 36, 179-201.

Preece, J. (2013). Africa and international policy making for lifelong learning: Textual revelations. International Journal of Educational Development, 33, 98-105. 
Right to Education. (2015). The UK's support of the growth of private education through its development aid: questioning its responsibilities as regards its human rights extraterritorial obligations.

http: / / www.right-to-education.org / resource / alternative-report-cescr-uk-ssupport-growth-private-education-through-its-development-aid

Roberts, A. (2015). Gender, financial deepening and the production of embodied finance: Towards a critical feminist analysis. Global Society, 29, 107-127.

Rappleye, J. (2011). Catalysing educational development or institutionalising external influence? Donors, civil society and educational policy formation in Nepal. Globalisation, Societies and Education, 9, 27-49.

Rose, P., 2005. Privatisation and decentralisation of schooling in Malawi: Default or design? Compare, 35, 153-165.

Shahjahan, R. A. (2012). The Roles of International Organizations (IOs) in Globalizing Higher Education Policy. In J. C. Smart, M. B. Paulsen (Eds.), Higher Education: Handbook of Theory and Research, Higher Education: Handbook of Theory and Research 27. Springer.

Tooley, J. (2004). Private education and 'Education for All.' Institute of Economic Affairs, 24, $4-7$.

Tooley, J., Bao, Y., Dixon, P., \& Merrifield, J. (2011). School choice and academic performance: Some evidence from developing countries. Journal of School Choice, 5, $1-39$.

Watkins, K. (2004). Private education and 'Education for All' - or how not to construct an evidence-based argument: A reply to Tooley. Institute of Economic Affairs, 24, 8-11.

Wilby, P. (2013, November 12). Professor James Tooley: A champion of low-cost schools or a dangerous man? The Guardian.

https: / / www.theguardian.com/education/2013/nov/12/professor-jamestooley-low-cost-schools

\footnotetext{
${ }^{\mathrm{i}}$ In July 2020, DfID was merged with the Foreign and Commonwealth Office to become the Foreign, Commonwealth, and Development Office (FCDO).

ii The UK's ODA saw an overall upward trend from 1999-when it was about US\$ 4.05 billion-to 13.4 billion in 2016 if inflation is adjusted at the 2016 price (DfID, 2017; Full Fact, 2018). In terms of ODA as a proportion of Gross National Income (GNI), the UK met the United Nation's target set in 1970 for all developed countries ( $0.7 \%$ of GNI) by 2013 and has maintained it at $0.7 \%$, a significant increase from $0.36 \%$ in 1970 (DfID, 2017; Donor Tracker, n.d.; Full Fact, 2018). The UK stood in fifth place after Luxembourg, Norway, Sweden, and Denmark among the DCA countries in terms of the ODA to GNI ratio in 2019 (FCDO, 2020).
} 